\title{
Lords ask for crisis handout
}

\section{London}

THE government should release $£ 12$ million immediately to prevent the cuts in research grants and studentships in 1991-92 announced by the Science and Engineering Research Council (SERC) last month, says the House of Lords Science and Technology (S\&T) Committee. SERC chairman Sir Mark Richmond has said that SERC will award only 50 per cent of the usual number of new research grants this year, and 85 per cent of the studentships (see Nature 349, 551; 14 February 1991).

The S\&T committee has been examining the circumstances that led SERC to cut its programme savagely, following the announcement of the 1991-92 science budget. Its report, published last Sunday (24 March), puts the heaviest burden of blame for the current crisis in the research councils onto the government: "The 1991-92 science budget falls far short of what is required to provide the basis for the continuing development of the country's science base."

The report says that the Advisory Board for the Research Councils (ABRC) had as- sumed that much of the $£ 23.3$ million of capital expenditure in 1990-91, on the research ship James Clark Ross and a new research councils headquarters building in Swindon, would automatically become available to be spent on research this year. Sir David Phillips, chairman of the ABRC, told the S\&T committee earlier this month that a number of new research programmes had been launched on this assumption, but the government had then decided that this money should not be built into the research councils "baseline" funding. The consequences of this decision are serious for all the research councils, the report says - all five have been forced to trim their future spending plans.

Somewhat surprisingly, however, the S\&T committee's report is lenient in its criticism of SERC under its former chairman, Sir William Mitchell. Mitchell committed SERC to spending on a number of large projects, beyond the planning figures given by the government, in the hope that some $\$ 40$ million of new money would be made available to SERC in 1991-92. In the event, SERC re-

\section{Confusion surrounds the 'Gardner effect'}

\section{London}

THE mystery surrounding the occurrence of clusters of childhood leukaemia cases around some British nuclear plants deepened last week. A team led by James Urquhart, of the Scottish Health Service in Edinburgh, found that the fivefold excess of leukaemia cases around the Dounreay nuclear fuel reprocessing plant in Caithness, Scotland, cannot be explained by the exposure of the leukaemic children's fathers to radiation at work.

Last year, a group headed by Martin Gardner, from the University of Southampton, found a strong association between the external doses of radiation received by men working at the Sellafield nuclear processing plant in west Cumbria before the conception of their children, and the likelihood of these children developing leukaemia (see Nature 343, 679; 1990). This was a controversial finding, as there is no known mechanism to explain the effect, and because no excess of leukaemia cases has been found in the children of Japanese atom bomb survivors, whose radiation exposure was higher than that of the Sellafield workers.

Urquhart's study, published in the British Medical Journal, looked at 14 children who developed leukaemia or nonHodgkin's lymphoma and 55 healthy controls. With such a small sample, the team say that they cannot confirm or deny the existence of the "Gardner effect". But the new Dounreay results show that Gardner's hypothesis does not explain the prevalence of childhood leukaemia in Caithness.

Urquhart's team did find that children who had played on the beaches around Dounreay were more likely to develop leukaemia. But the researchers believe that this result may be an artefact of repeated statistical significance testing, or may have been affected by biased questionnaire responses from the parents of leukaemic children.

A second study published in the British Medical Journal last week adds to the confusion. Patricia McKinney, from the University of Leeds, and colleagues have looked at the parents of children with leukaemia in west Cumbria, north Humberside and Gateshead, all in the north of England, to identify any links between parental occupation and the occurrence of leukaemia in children.

McKinney's team found that a number of parental factors correlated with the occurrence of leukaemia, including paternal exposure to radiation. The factor most strongly associated was the parents' exposure to wood dust at work - a factor never before implicated in the disease. But McKinney's team did not quantify the parents' exposure to each of the factors they considered. In an accompanying leading article, Peter Smith, from the London School of Hygiene and Tropical Medicine, says that the study should be seen as generating some interesting hypotheses to be tested further, rather than providing strong evidence of new causative factors.

Peter Aldhous ceived only $£ 12$ million. In 1991-92, research grants and studentships, as the only item of SERC's expenditure which can be cut easily, have suffered heavily.

The $£ 12$ million emergency fund requested in the report would reinstate these grants and studentships, described by the committee as "the very seed corn of the United Kingdom science base". But the report warns that the fund will provide only a temporary solution to what is a serious underlying problem. The Universities Funding Council's (UFC) spending on research has been falling steadily since $1987-88$, the report says. This has meant that the total funding for academic science has fallen in each of the last two years. The S\&T committee says that the government should use the "period of grace" allowed by the $£ 12$ million emergency fund to rethink its policy on science, and suggests a number of changes.

The Cabinet committee on science and technology, which is chaired by the Prime Minister, should involve itself more heavily in deciding the level of funding for the science base, the report says. The committee is worried that purely financial considerations dominate over scientific strategy in the annual discussion between the Treasury and the Department of Education and Science. The advice given to the Education and Science Secretary by the ABRC on the size of the science budget should be published to allow informed debate on science funding, according to the S\&T committee. (This practice, established in the early 1980 s, was abolished last year.)

The S\&T committee is also concerned that the planned transfer of some $£ 100$ million a year of the UFC's spending on research to the research councils, which begins in 199293, will undermine the universities' ability to support young researchers. This $£ 100$ million is supposed to pay for the indirect costs associated with research-council-funded projects in higher education institutions. But these costs have proved difficult to identify, the committee says. Unless a fully workable scheme can be put in place soon to ensure that the transferred money is actually used to support research in the universities, the transfer should not go ahead, the report says.

But the government has so far shown no willingness to provide the $£ 12$ million emergency fund, let alone launch a wholesale review of its science policy. Education and Science Secretary Kenneth Clarke last week expressed sympathy with young researchers who will be denied research grants in the coming year, but told the S\&T committee that the government could not bail SERC out. Otherwise, the other research councils would also start overspending, he said.

The research councils' financial problems were also compounded last week by a change in British taxation. Chancellor of the Exchequer Norman Lamont has added 2.5 per cent to Value Added Tax, a surcharge on purchased goods, which will increase the cost of scientific equipment.

PeterAldhous 